\title{
A Materialism For The Masses: Saint Paul and the Philosophy of Undying Life, by Ward Blanton
}

Insurrections: Critical Studies in Religion, Politics, and Culture | New York: Colombia University Press, 2014 | 264 pages | ISBN: 978-0-23I-I6690-4 (hardcover) \$105.00 | ISBN: 978-0-23 I-I 669 I-I (softcover) \$35.00| ISBN: 978-0-23 I-536455 (ebook) \$34.99

Rarely does a book come along that so deeply

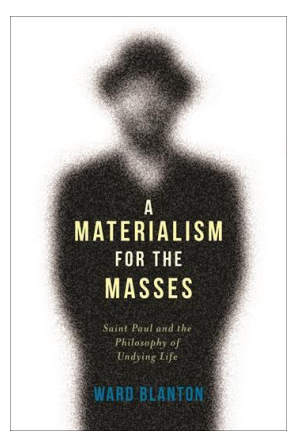
challenges our exegetical preconceptions. A Materialism For The Masses: Saint Paul and the Philosophy of Undying Life (AMM) opens up new ways of understanding the shared genealogies and the competitive struggles of biblical studies and philosophy within European academic contexts and then appears to pull off the most audacious stunt of all: blazing a trail out of the contemporary deadness and stultification of a Christianity that has inverted and repressed all the important indications of a vibrant life. What is also remarkable about its approach is that while its intentions are incredibly exciting and potentially effectual in stimulating change, the "Paulinism" and the "Paul" championed by it could be adjudged flawed, in the sense that they are appropriations whose gamble risks everything, but which may have fallen short of the radical transformation of "the forces of markets, religions, and social hierarchies in relation to the difficult questions about human freedom," which it so passionately seeks to achieve.

It is the contention of this review that Ward Blanton's methodology and tactics in principle are more than sound-outstanding in fact-but his "Paul" is a construct and a hero that might best be served by other models. I will propose that all that Blanton hopes for is, ironically, to be found in Friedrich (Nietzsche) not his Paul, and that the "Jesus" Nietzsche admires isn't too vast and doesn't deserve to be overlooked any more than the equally new exciting theologies that arise around Nietzsche. Now it could be that in the end we, Ward and I both, will be found idolaters in the Nietzschean sense. However, the great strength of the book under review, is that it allows, graciously so, room for movement and exploration in surprisingly fresh 
theoretical and praxeological ways. As Blanton's intimations in a past interview suggest, the enterprise is, oddly for its context, a rigorously intellectual endeavor that is at once a spiritual and a social practice as well as one that

will come in forms we're not aware of yet. And that's necessary, that's clear: whatever will come will come in ways we're not yet aware of-otherwise the Messiah wouldn't be dead.... [It will be] a kind of forceful beginning to a cultural metanoia ... the signs of a dynamic intellectual community [where] people lose themselves, become different, associate with different people, reorient their families, ethnicities, articulate these things differently in relation to the inherited genealogies of political association.

Only such communities as Blanton holds up for us, it is certain, can persuasively gainsay those "machineries of the manufacture of profitable death [that are] 'more real' than those protesting against them." Notwithstanding, the models we use to help materialize those protesting machineries must themselves prove their reality to be as real as the machineries they oppose.

So, the central questions posed by this review are these:

(a) Is the model of Paulinism proposed by Blanton resilient enough, "real" enough to hold its own with the brutally antagonistic and duplicitous world in which it cohabits?

(b) And while Blanton's trust in "the excess and creativity of our being," is a worthy one and will serve us well in the discursive review which follows, is such creativity to be actually found in his Paulinism? Or is it more a case that the superimposition of the creative ideas that arise from the writings of Gilles Deleuze, Felix Guattari, and others like Michael Hardt and Antonio Negri, from whose writings Blanton draws inspiration, make "Paul's" writings appear more creative than they really are?

(c) And finally, and most important of all, do Nietzsche and the classicists really "have Paul totally wrong," the presumption upon which Blanton's entire case is built? 
Firstly then, is the question of the viability and resilience of Blanton's Paulinism. In the conclusion to the book, he returns to its premise drawn from Sigmund Freud's Moses and Monotheism in which Freud draws attention to an insidious process: two distinct forces (diametrically opposed) which are at work in influencing the way we read texts upon which the perceptions of important figures in our intellectual and religious and cultural history, such as Moses, are shaped and formed. First, there are the processes that actively but secretively work to falsify and to transform the meaning of the text into its opposite. Second, there are the other forces, which seek to promote a reading that champions indulgent, pietistic intentions to uphold the status quo ("keeping everything as it stood"), what we might call traditional readings regardless of "whether the details [fit] together or [nullify] one another." The only way, Freud argues, by which we can detect such forces, is to be alert to "striking omissions," "repetitions" which ultimately distort, violate, "kill" the integrity of the text and its author-a kind of targeted assassination, if you will, to silence the dissenting voice.

But while Blanton's entire project here is based on Freud's analogy of a murder, he nevertheless contends that neither Freud nor Nietzsche go far enough ("not sleuthing hard enough," "not doing enough dreamwork on the force and forms of cultural memory"). Blanton argues that Nietzsche (with Freud in tow) doesn't critique the premise (promulgated by the Church universal, the Lutheran Church specifically in his case) that Paul himself and Paulinism constitutes the operative break between Judaism and Christianity. In effect, Blanton argues that this Paul is nothing more than a convenient "fable," a construct to ingratiate Christianity with the Empire by distancing itself from Judaism (often but not always perceived as subversive against Rome), and insists that both Nietzsche and Freud have taken the fable as fact, and so fool them. Because when you expose the omissions, become aware of the distortions and finally understand that the real Paul lies at the bottom of a swamp weighed down by "sacred cement shoes," and that you've only been dealing with a phantom Paul, one that has magically through smoke and mirrors floated up from the bottom of the murky waters of deception, then of course you're going to have to change your genealogical theories. And while there is much biblical scholarship to confirm that the Paul we think we're dealing with is not the "real" Paul, who is more Jew than Christian, does it necessarily follow that the genealogical arguments proposed by Nietzsche and Freud ipso facto are thereby to be discounted, particularly as Blanton does offer some significant concessions to Nietzsche, and clearly thinks 
highly enough of Freud to make his pronouncements about textuality and Moses the bookends for his project?

For instance, vis-à-vis Nietzsche, Blanton makes the following concessions:

(a) "Nietzsche's nevertheless brilliant reading of the Pauline texts" (35);

(b) "Nietzsche was perfectly correct to see in the emergence and spread of Christianity a kind of pop Platonism" (35);

(c) "[this] genealogist of the material soul of the West [in saying that] 'before [Paul] there were only a few Jewish sectarians" had "an astonishingly important insight that must be pressed much further ..." (36); and finally,

(d) "Nietzsche's [analysis] is here perfectly correct" (36; although what the exact "correctness" is in the context, is somewhat ambiguous).

Our question might be: how can one so brilliant, so meticulous and so correct have got it so wrong? But the more pressing question must be this: does Blanton's sleuthing overreach itself in the sense that it creates a Paul that purports to affirm the most recent discoveries of biblical studies, but exceeds that brief by evoking a Paul that is in danger of becoming a paradigm designed merely to serve the interests of the ever-changing and fluid purposes of combatting those "forces of markets, religions, and social hierarchies in relation to the difficult questions about human freedom"?

That Blanton's "Paulinism" is fashioned and shaped by the quest for a paradigm comes out very clearly in statements made in an interview with Daniel Oudshoorn regarding his philosophical reading of Paul, conducted after the book was published. ${ }^{1}$ First, Blanton claims that his Paul ("my Paul") may serve as a "rock-throwing" missile (the prophet Daniel's stone comes to mind which targets the feet of the arrogant statue celebrating economic and military imperialism, a stone designed to topple it - not sure whether this is what Blanton envisaged). This is, in effect, a "lawlessness from below" countering the "lawlessness from above," which for Blanton becomes a rallying cry for his brand of Paulinism. And from such "stone throwing, the

${ }^{1}$ Daniel Oudshoorn, "What Is a Paulinist To Do?", On Journeying with those in Exile, October 30, 20I4, https://poserorprophet.wordpress.com/interviews/. 
controlled lawlessness, by this destruction of false 'solidarities,"' he hopes for an emergence of "new solidarities and new visions of what it means to be in solidarity." Second, the rock, desirably, is capable of becoming a book in search for new ways of reading religion and politics, new ways of understanding economics and developing a new philosophical and religious genealogy. This includes philosophy's celebration of true Paulism in the guise of "truth as scandal," for solidarities around the truth always involve a cut, a scandal, a drawing of division, claims Blanton. And those times of engagement with the forces that would cover up, deceive, rob us of life, he names "messianic time":

[those] moments [where] there is simply no other option than to think, feel, act differently. The real is breaking out, exceptions are tearing the usual symbolic fabric of people's lives, and this pressure- this violence-forces out of us new associations, new ideas, new desires, new ways of living.

A potentially wonderful outcome-there's only one problem: these moments are not within our control, it seems. Because "Paulinist messianism" won't be controlled, "even if you or I wanted to try it." And here are the first indications of the soft underbelly of Blanton's Paulinism: it's not in the end a paradigm we can depend on - it seems to be predisposed to violence, and overall, seems to have no control over the kind of transformation that eventuates. All we can be sure of is that it will be new, that it will be disruptive, and that neither the kind of the desires, nor the kind of life that it produces, are, in terms of the quality of its associations and ideas, guaranteed. "New" maybe, but not in the end-manageable.

Oudshoorn's challenge in the interview, when it comes, is a timely onequestioning not just whether the paradigm is out of control but also, "how much of this rhetoric is just bluster?" inasmuch as the Paulinist aspirations seem not to be grounded in the real world of activism. And Blanton's initial reply, "I'm quite serious when I say: we do not yet know what a Paulinist can do," does nothing to reassure us. We feel an excitement in the belly, yesbut is this just a "theoretical free-fall" with either no end in sight or a nasty, unwanted end-point waiting to happen-perhaps even a dead end?

Yes, it is true, the evidence is incontrovertible: there are repressive forms of cultural memory and a "cultural memory in the present" that occlude reality, things as they are-but after we expose them, after we have brought those memories to the surface, what will we $d o$ with them, how will we un- 
ravel them, how will we use this knowledge to transform the social, political and economic structures that oppress us from above?

The seemingly straightforward task of "simply need[ing] to know what's happening, where, how, in what names, with which vibrancies," suddenly turns out to be not so simple. Are the "unremarked moments" doomed to be "simply lost in repressive forms of cultural memory," an essentially invisible "cultural memory in the present," an abstraction that never actually materializes, further complicating the challenge of how to locate and identify in the midst of the in-between spaces, "the usual spheres of speaking, saying, gesturing about Paul"? How do we attain unto the "becoming" that is genuinely, "a displacement of the pre-existing categories in question"? Or, again, putting it another way, using Blanton's terms of reference, how do we go beyond our petty small stone-throwing and smashing of windows, to an effective seismic disruption and dislocation that is powerful enough to dislodge systemic abuses of power in the way the prophet Daniel envisions it - the small yet effective messianic stone that brings down the whole proud, self-deluded edifice? These are questions to be asked — lest we fall into a kind of autism that disconnects us from the emotional complexities and nuances which envelop us.

Why is this Paulinism of Blanton's so important? Why is "getting Paul," "understanding Paul," a "massively important observation"? Putting it another way, does the crucified messiah even need a Paul? If his book is in fact, "a kind of forceful 'beginning' to a cultural metanoia," is this the methodology we employ to achieve it? Or do we look for something else-another? Fundamentally, whatever is proposed, the someone and the something-are they up to the task of the "massive excavation of the archaeology of the Western soul" that is so urgently required? And will this Paul, given that Blanton sees him as totally stranded "between the Jerusalem bunch he wanted to please but also wanted to dismiss; between a desire for recognition and a desire to chart new territories," will he in the end, Blanton asks, be snubbed by the philosophers he wants to emulate? Or will he serve simply as the vital and necessary interlocutor we needed to have?

I think this is the point where Blanton takes us to the heart of the matter, the raison d'etre for his book and indeed his life purpose. His is, in the $A M M$ project, first and foremost a journey of exploration that takes us "to the other side of the sublimating narratives of Christian origins" which have so deeply shaped modernity; a journey that in its momentum tears away the "beatified" death mask that the "great machinery of Christendom and its pop Platonic 
narration of Christian origins" has created for the falsified Paul (I85). It is at times a crazy hippodrome chariot ride that wrenches us around a tight turn to reveal "an arena of immanence from which none of us can escape" (I 86). And it is right here, claims Blanton, that we find the "real Paul": not the metaphysical Paul (the fabrication of Christendom's great machinery) but the Paul who rides the current of a new "materialist spirituality," an "immanent religiosity" and who, if he were allowed, speaks to our generation in such a manner that it transforms "the very framework of this metaphysics itself" (I 86), a "genealogical Verwindung of a hegemonic Pauline narrative" (I 87) which has somehow eluded, he claims, Nietzsche and Freud, and continues "to plague recent radical readers of Paul."

As we tear around that hippodrome corner (a Nietzschean allusion) what does the real Paul look like, sound like? Is this the much vaunted "materialist," the universalist, the innovationist who eschews metaphysics and embraces "transcendence" and "immanence" as the only reality that is truly transformative precisely because it rises above self-deception and self-delusion, and a reality that produces the authentic "messianic" moment? Is it Paul the Jewish dissident, the insurrectionist whose blood like that of Abel and the long line of assassinated prophets, cries out to be heard and is heard by the One who is the listener whose verdict finally matters? Or is it, in the end, only the crackling sounds of a distorted voice whose message is caught in snatches created by Eusebius? Or did Eusebius only imagine he heard it, an imagination according to Blanton, that found it necessary to demonstrate "the divine character of Christian origins" (History of the Church I.I.2.2-3) (cited, 7), and prove "Christianity's discontinuity with its histories or pasts" (7)? This Blanton takes to be a misrepresentation of the apostle as, "a hero invested with a foundational greatness" (6), and so "a shrewd form of cover up" (7). If this is true, Blanton's outrage is totally understandable, and his disappointment in Nietzsche for inadvertently perpetuating the myth of Paul as the first Christian to suit his own (Nietzsche's) genealogical agenda seems well attested.

"The Divinity Managers" as Blanton names them in his essay "Satellite Skies; or, The Gospel and Acts of the Vampirisms of Transcendence,"2 or "imperial Christianity's interpreters" (92), have manufactured a "Christian" break from Judaism, suppressing the "rich and diverse tradition of early Jew-

\footnotetext{
${ }^{2}$ Ward Blanton, "Satellite Skies; or, The Gospel and Acts of the Vampirisms of Transcendence," in An Insurrectionist Manifesto, Four New Gospels for a Radical Politics, ed. Ward Blanton et al (New York: Columbia University Press, 2016), 87.
} 
ish partisanship and contestation of inherited norms of all sorts" (92). And changing our terms of reference, and back to when the "real" body of the real Paul is released from his concrete shoes floats to the surface, "indistinguishable from a new materialism" (I9I), what we have in effect surrounded by yellow tape is a "crime scene of a significant textual murder" (I9I). That case I think has been well and truly nailed. But to my mind, given the much more nuanced research on St Paul and Nietzsche's stance on St Paul that is available and ignored by Blanton, there are two questions which remain unaddressed: are there other suppressions exposed by the most recent and on-going research in New Testament scholarship which might modify our views on the "real" Paul; and, finally, do Nietzsche and the classicists have Paul totally wrong? I would posit that the most serious scholarly research on Nietzsche, to wit, Christa Davis Acampora's Contesting Nietzsche ${ }^{3}$ reveals a Nietzsche whose stance on Paul is in line with Karen Williams's findings in "Paul-making History: In Search of a Sartrean Biographical Method,"“ but also (perhaps to Blanton's surprise) uncovers a Nietzsche more in line with his own thinking than he imagines.

Did Nietzsche fail to distinguish between Paul and the place of the inscription of this name manufactured by the "cultural memory of Christian origins"? Did he, then, by "reif[ying] Paul, [leave] his place in the archive of Western ontotheology unscathed, forcing the philosopher only to disavow, rather than to transform, the effective Pauline legacy" (36)? Was Paul in fact, "not the first Christian, but was made to be so for very questionable ends" (37)? And from that perspective, is this form of sublimation, converting Paul the Jewish partisan into Paul the first Christian by "an emerging church longing to become a darling of the empire," (37) similar to its Jewish equivalent as explored by Freud, Moses the Egyptian transformed into Moses the Jewish partisan, so Blanton is able to say, when all the suppressions are removed and the "true" personae are revealed: "Moses the Egyptian meet Paul the Jewish partisan" (38).

In its essentials Blanton's case against the Divinity Managers is incontrovertible. I share his outrage. But so does Nietzsche. He also uncovers the Pauline distortions as Martin Liebscher underlines in his essay on The Anti-Christ:

${ }^{3}$ Christa Davis Acampora, Contesting Nietzsche (Chicago: University of Chicago Press, 2013).

${ }^{4}$ Karen Williams, "Paul-making History: In Search of a Sartrean Biographical Method," PhD diss., University of Toronto, 2014. 
The psychology of the redeemer is important to Nietzsche's critique of Christianity, as it enables him to separate the redeemer on the Cross from the distortions that were introduced by his followers after his death.... This was the beginning of what Nietzsche called the Dysangelium (AC \$39; KSA 6,2 I I).... The height of this distortion was reached with the Apostle Paul—for Nietzsche, the epitome of the priest's will to power-who invented the early history of Christianity and even forged the history of Israel in order to justify his claim for Jesus as Messiah. ${ }^{5}$

This is exactly what Blanton has been arguing for, with this caveat: that he accuses Nietzsche for not taking his critique far enough, and so blaming "Paul" when in fact Paul himself is not to blame, but the Church at large. But I would contend that Nietzsche's argument is with the Lutheran Church and its use of Paul (and by the way, in Nietzsche's view, the Christ of the Evangel is the only true Christian). Acampora places Nietzsche's "contesting Paul" in the larger context of "agonisms": contesting Homer, Socrates, Paul, and Wagner. She makes, for our purposes, the crucial observation that, "if Christianity is 'Platonism for the people,' Nietzsche's attack on Pauline Christianity [is] an outgrowth of his struggle with Socrates" (I I 2). Nietzsche's contest with Paul, as Acampora sees it, includes the following grievances (her treatment is far too nuanced and exhaustive to do her justice here):

(I) St Paul, like Socrates is accused of displacing public contests by "psychic or spiritual ones." Nietzsche claims that St Paul champions a spiritualized contest of Christianity that "aims at the destruction of the opponent, and thus, is motivated by Vernichtungslust (the desire for destruction) but it does not really distinguish foe from friend since it aims at the self-destruction of those over whom the power of faith is exercised just as much as it seeks the destruction of the enemies of Christianity" (I I3).

(2) Saul's conversion (see Saul's Kampf in Daybreak, 68) is driven by Vernichtungslust (desire for annihilation), "his wild thirst for power [aussschweifende Herrschsucht]." "He

${ }^{5}$ Martin Liebscher, "The Anti-Christ," in A Companion to Friedrich Nietzsche: Life and Works, ed. Paul Bishop (New York: Camden House, 201 2), 352. 
pursues his liberation through revenge against the law," claims Acampora (I I6).

(3) The abolition of the law, through the figure of Christ, "frees Saul to seek distinction through other means" ( I I 7).

(4) The "genuine history of Christianity" argues Nietzsche, must be distinguished from Christian doctrine and dogma as the life of Christ: "in truth there was only one Christian, and he died on the cross. The 'evangel' died on the cross. What has been called 'evangel' from that moment was actually the opposite of that which he had lived: 'ill tidings,' a dysangel” ( I I7-I 8, citing Anti-Christ, 39).

Consequently, while I agree with Blanton that Nietzsche has blamed "his" Paul for what is attributable to "the dominant history of Christian reading of Paul," 6 in defence of Nietzsche, his main argument is in fact with that Church's (the Lutheran Church's) use of Paul. Acampora notes, for example, that Paul's revenge finds its legacy in Lutheranism and Luther's Bible and its use of Wettkampf and Kampf "appear nearly exclusively in the writings attributed to Paul" (II7). In reality, Niezsche's contest with "Paul" is his agon with the Church. In that respect, Blanton and Nietzsche are on the same page.

This brings me finally to Williams's research, and her dissertation. What follows is a summary only, but reveals I think some strong correspondences between Blanton's findings and Nietzsche, making a case for Nietzsche's inclusion in the Blanton canon, rather than his exclusion. Despite her disclaimers, Williams's methodology is meticulously historical and textual and her findings encompass the following central conclusions (347-50):

(a) Paul's contested apostleship connects him with a socially degraded and vulnerable Messiah, creates opportunities for food and shelter and promises him hope of a liberated body and eternal rule with a Maccabean-style ruler.

(b) The term "Remembered Paul," writes Williams, "create[s] ... distance between the life of the ancient man named Paulos and the life that is represented in the manuscripts, and the life that is re-constructed by scholars, including myself."

${ }^{6}$ Blanton, "Satellite Skies," 86. 
(c) The proposal of a methodological framework that provides the basis for an identification of biographical evidence (translated into a biographical ensemble of "facts") of the Remembered Paul relies on the earliest extant manuscript evidence rather than on the scholarconstructed "Pauline Corpus" from the canonical New Testament.

(d) Sartre's philosophy has created an opening for scholars to imagine a Paul with needs, feelings, hopes, and concerns which do not float above the social world in which he lived, but were formed (though not completely defined) by the social situation(s) in which he lived. Sartre's Marxist-Existentialism avoids the extremes of both psychological and sociological interpretations, and creates a well-reasoned theory of human action.

Williams's findings are intriguing and the discoveries she makes enrich our reading of Paul's works, Nietzsche's critique, and Blanton's Paulinism project. They include (drawn from Williams's reading of Galatians) the following "evidence" regarding the Remembered Paul (RP). And when that evidence is cross-referenced with Acampora's project, Contesting Nietzsche, which she says "haunted, irritated, seduced and excited me for virtually all my professional life to date" (xi), a remarkable consensus arises, as will be seen:

(a) The first fact links with Zealous Israelite, and further defines RP as formerly zealous for Torah in a Maccabean style (330).

(b) The second fact links with RP as a socially depraved and vulnerable man, and further describes him as bearing the same marks of slave discipline and capital punishment that Jesus suffered. The socially degraded and vulnerable Israelite ... is constant across RP (330). Jeremy W. Barrier concludes that "it reveals Paul's suppressed status as a colonized Jew looking for an alternative language to express his deep need for a master worthy of his loyalty."

${ }^{7}$ Jeremy W. Barrier, "Marks of Oppression: A Postcolonial Reading of Paul's Stigmata in Galatians 6:17," Biblical Interpretation I6 (2008), 339, cited by Williams. 
Williams goes on to note that, "Paul is comparing the marks of capital punishment (stigmata) that Jesus bore on his body to the stigmata that he bears on his body as well. Whether he is making a tight comparison (both were tattooed slaves) or a loose comparison (the marks of punishment may vary, but the experience of capital punishment is the same), the importance of the word stigmata is that Paul claims that, like the body of Jesus, his bears the marks of capital punishment" (340).

(c) Apostleship, with concerns about material support, ongoing work of "the collection," competition between messengers has been described. RP's envisioned future is linked both with the material realities of apostleship, and his socially degraded body. We now have the basis for an interpretation of the larger movement of apostleship against which Ioudaismos ("works of the law," specifically circumcision) and a stigmatized slave (proof of capital punishment) are specifically at play in Paul's Letter to the Galatians (330).

(d) RP's Letter to the Galatians is his action upon his material situation of scarce resources, and competition for objects of "boasting." It makes sense of his biographical ensemble, his envisioned future, and the present realities of an apostleship that is contested and precarious (34I).

In sum, Williams's research (far more elaborate than can be represented here) confirms Nietzsche's and Blanton's contentions that the New Testament canon, when you strip away its veneer, is all about the Early Christian community's manufacturing of a more "acceptable" Paul in terms of being "Empire friendly unlike Judaism" (Blanton); or a more "authoritative" Paul re-fashioned to be more persuasive in the context of strong competing interests amongst a plethora of "other" apostles/messengers. The latter finding, adds strength to Nietzsche's contention that the Paulinist project arose out of ressentiment (review Acampora's note, citing Nietzsche): the abolition of the law, through the figure of Christ, "frees Saul to seek distinction through other means" (I I 7 ). Acampora's analysis of Nietzsche's "contesting Paul" overall renders this impression unmistakable and irrefutable: Paul corrupts the agon; as a consequence we have the "pseudocontests engineered by 
Christianity to give the appearance and lure of contest" (Genealogy of Morals III:I7-2 I; I2I); "the slavish lack the physical strength requisite for victory in [physical] struggles... and redefine the realm of contest as psychic space in which nonphysical strength is tested. They tap the energy of revenge to dominate that sphere" (cited on page I 23); the list goes on.

This review ends as it began: Blanton's analysis is amazing, a must read for any serious Paulinist scholarship. It promises and delivers on the possibility of "an open-ended archive, a West without grounding coordinates in names like theology, religion or the political, that [makes] a reading of Paul become all the more compelling" (194). And even if, in the opinion of some, it fails to convince us of the fact that Nietzsche and the classicists really "have Paul totally wrong," and that Paul is a much misunderstood "insurrectionist," Blanton's challenge is, in the end, one to be taken seriously: "Moses the Egyptian ... please meet Paul the Jewish partisan."

Nikolai Blaskow

Bangor University 